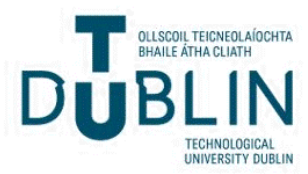

Technological University Dublin

ARROW@TU Dublin

2016-3

\section{Amorphous Silicon Solar Vivaldi Antenna}

\author{
Oisin O'Conchubhair \\ Technological University Dublin \\ Kansheng Yang \\ Technological University Dublin \\ Patrick McEvoy \\ Technological University Dublin, patrick.mcevoy@tudublin.ie
}

See next page for additional authors

Follow this and additional works at: https://arrow.tudublin.ie/engscheleart2

Part of the Electrical and Electronics Commons, Electromagnetics and Photonics Commons, and the Electronic Devices and Semiconductor Manufacturing Commons

\section{Recommended Citation}

O'Conchubhair, O., Yang, K, McEvoy, P \& Ammann, Max. (2016) Amorphous Silicon Solar Vivaldi Antenna, IEEE Antennas and Wireless Propagation Letters, vol. 15, pp. 893-896. doi: 10.1109/LAWP.2015.2479189.

This Article is brought to you for free and open access by the School of Electrical and Electronic Engineering at ARROW@TU Dublin. It has been accepted for inclusion in Articles by an authorized administrator of ARROW@TU Dublin. For more information, please contact arrow.admin@tudublin.ie, aisling.coyne@tudublin.ie, gerard.connolly@tudublin.ie.

Funder: Part funded by the Irish Higher Education Authority 


\section{Authors}

Oisin O'Conchubhair, Kansheng Yang, Patrick McEvoy, and Max Ammann

This article is available at ARROW@TU Dublin: https://arrow.tudublin.ie/engscheleart2/196 


\title{
Amorphous Silicon Solar Vivaldi Antenna
}

\author{
Oisin O'Conchubhair, Kansheng Yang, Patrick McEvoy, Senior Member, IEEE \\ and Max J. Ammann, Senior Member, IEEE
}

\begin{abstract}
An ultra-wideband solar Vivaldi antenna is proposed. Cut from amorphous silicon cells, it maintains a peak power at $4.25 \mathrm{~V}$ which discounts the need for lossy power management components. The wireless communications device can yield solar energy or be configured as a rectenna for dualenergy harvesting. The solar Vivaldi performs with $0.5-2.8 \mathrm{dBi}$ gain from $0.95-2.45 \mathrm{GHz}$. In rectenna mode, it covers three bands for wireless energy scavenging.
\end{abstract}

Index Terms-Vivaldi, Ultra-wideband, Amorphous Silicon Solar Cell, Energy Scavenging.

\section{INTRODUCTION}

$\mathrm{T}$ HE number of wireless sensor networks is ever increasing and with it, the requirement to replace and dispose of discharged batteries. Consequently, devices that harvest energy from their environments are desirable [1]. Solar cell energy sources compete with antennas for surface area on the device, making it attractive to combine the technologies.

In [2], a Hydrogenated Amorphous Silicon (a-Si:H) solar cell constituted an ultra-wideband monopole antenna with a bevelled copper feed for use as a wireless sensor. Simulated results showed the $2-10 \mathrm{GHz}$ antenna had $0-3 \mathrm{dBi}$ gain. The average power consumption by the sensor was $29 \mu \mathrm{W}$, which could be supported for more than 48 hours using a $500 \mathrm{mF}$ storage capacitor. In [3], a pair of a-Si:H cells were adapted to form a $3-10 \mathrm{GHz}$ dipole antenna with a $3 \mathrm{dBi}$ peak gain. The average power consumption of the sensor was $55 \mu \mathrm{W}$, which lasted 95 minutes using a $70 \mathrm{mF}$ storage capacitor. Both [2] and [3] require lossy boost converters to convert their $0.7 \mathrm{~V}$ $\mathrm{DC}$ voltage to $3.8 \mathrm{~V}$ for use.

In [4], a panel of three a-Si:H solar cells constituted an aperture coupled slot antenna with $3.5 \mathrm{dBi}$ gain at $2.4 \mathrm{GHz}$ and $3.1 \mathrm{dBi}$ gain at $5.2 \mathrm{GHz}$. While the $3.8 \mathrm{~V}$ output Voltages avoided lossy power management circuit components, the antenna slot resulted in a 27\% reduction of the solar cells area.

Wireless energy scavenging [5] from $0.35-3 \mathrm{GHz}$ showed 8 bands that sum to $195 \mathrm{MHz}$ which could support low-power sensor devices. While scavenged power was small [6], lowpowered microcontrollers (e.g. 24FJ series PIC) can maintain a deep sleep mode without data loss using $132 \mathrm{nW}$ [7].

Manuscript received April $2^{\text {nd }}, 2015$. This work was part funded by the Irish Higher Education Authority under PRTLI Cycle 5 as part of the Telecommunication Graduate Initiative. O. O'Conchubhair, P. McEvoy and M. J. Ammann are with the Antenna \& High Frequency Research Centre, School of Electrical and Electronic Engineering, Dublin Institute of Technology, Kevin St., Dublin 8, Ireland (e-mail: oisin.oconchubhair@mydit.ie; patrick.mcevoy@dit.ie; max.ammann@dit.ie).
A 2.4 - $2.46 \mathrm{GHz}$ Vivaldi antenna made of copper produced a $0 \mathrm{dBi}$ gain to feed a rectifier [8]. With $22 \mu \mathrm{W} / \mathrm{cm} 2$ incident power densities, the rectenna had a $2 \mathrm{~V}$ output.

Fig. 1 shows a Vivaldi antenna, which for the first time, was cut from a panel of Amorphous Silicon (a-Si) solar cells. It was designed for wireless communications, with complementary solar energy harvesting, or to act as a rectenna for dual-energy harvesting. The Vivaldi cut out separated two strings of solar cells in the panel and minimised the loss of solar voltaic generation. The antenna had a directive radiation pattern and wide frequency range that included GSM and WLAN bands. With a peak power at $4.25 \mathrm{~V}$, the a-Si cell could power a wireless sensor without a lossy boost converter or a voltage regulator.

Where the antenna might be applied to wireless scavenging, it would complement the loss of solar energy during hours of darkness and supplement the supply during daylight.

\section{Proposed Antenna Configurations}

A coplanar Vivaldi antenna was cut from a $0.6 \mathrm{~W}$ a-Si panel of ten solar cells arranged in a series of 5 pairs of parallel connected cells [9]. The $400 \mathrm{~nm}$ thick a-Si layer of each cell was $71 \times 18 \mathrm{~mm}$ and separated from other cells by a $2 \mathrm{~mm}$ gap [10]. Each cell had 7 silver electrodes on the front contact. The electrodes are $0.5 \times 16.5 \mathrm{~mm}$ and separated by $9.5 \mathrm{~mm}$. Rear contacts, $19.9 \times 146 \mathrm{~mm}$, provided parallel connections between cells and were isolated from adjacent contacts by a $0.1 \mathrm{~mm}$ gap. The low-cost flexible panels were manufactured for one of many different power configurations and the layout enabled various antenna shapes. End edge contacts on the panel were made from tin-coated copper plate. The entire panel was encapsulated by flexible polyimide layer.

Equation (1) describes the exponential curve of the Vivaldi antenna where $x_{0}$ was the first point of the curve and $g r$ was the rate of change in the curve [11].

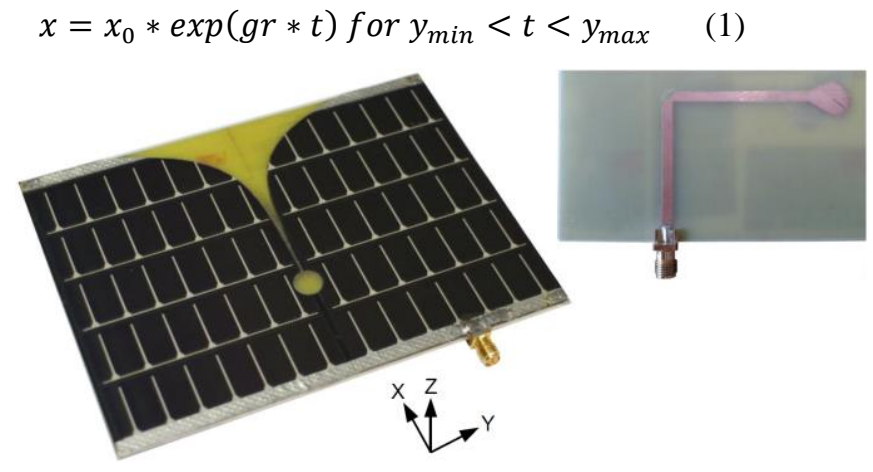

Fig. 1. Solar Vivaldi antenna (left) and rear-side transmission line (right) 
TABLE I

SIMULATED MICROSTRIP-TO-SLOTLINE TRANSITION RESULTS

\begin{tabular}{|c|c|c|c|c|c|}
\hline \multirow{2}{*}{$\begin{array}{c}\text { Stub } \\
\text { Length }\end{array}$} & \multirow{2}{*}{$\begin{array}{c}\text { Lower }-10 \mathrm{~dB} \\
\text { limit } \\
(\mathrm{GHz})\end{array}$} & \multirow{2}{*}{$\begin{array}{c}\text { Cell Area } \\
\text { Removed } \\
(\%)\end{array}$} & \multicolumn{3}{|c|}{$\mathrm{S}_{11}$ at } \\
\hline & & & $\begin{array}{c}0.95 \mathrm{GHz} \\
(\mathrm{dB})\end{array}$ & $\begin{array}{c}1.87 \mathrm{GHz} \\
(\mathrm{dB})\end{array}$ & $\begin{array}{c}2.45 \mathrm{GHz} \\
(\mathrm{dB})\end{array}$ \\
\hline $10 \mathrm{~mm}$ & 0.98 & 2.29 & -8.9 & -22.4 & -10.2 \\
\hline $12 \mathrm{~mm}$ & 0.84 & 3.49 & -16.8 & -21.1 & -9.8 \\
\hline $14 \mathrm{~mm}$ & 0.74 & 4.93 & -28.4 & -17.5 & -9.8 \\
\hline
\end{tabular}

The antenna was fed with a $50 \Omega$ microstrip transmission line printed on the FR-4 substrate used to support the solar panel. The transmission line was terminated in a microstrip to slot-line transition between a quarter wave radial stub and quarter wave circular slot. Table I summarises preliminary simulations with CST Microwave Studio that optimised the stub length to support a band lower than GSM-900 while minimising a circular slot in a copper layer. Having built the simulation model to include the entire solar panel and antenna, final dimensions were optimised for the Vivaldi slot.

The simulated solar Vivaldi antenna was designed with the minimal amount $(3.6 \%)$ of silicon removed. The slot location was varied to $35 \mathrm{~mm}$ from the symmetrical centre between the cells with a loss of $5 \%$ of a-Si. While a $5 \mathrm{~mm}$ offset had minimal impact, the $35 \mathrm{~mm}$ offset reduced the bandwidth by $294 \mathrm{MHz}$ to remove the $900 \mathrm{GSM}$ band.

The silicon-optimised features were copied in double-sided copper on an FR-4 substrate for performance benchmark.

\section{RESULTS AND DISCUSSION}

The $S_{11}$ results and simulated efficiencies are summarised in Table II and plot comparisons are shown in Fig 2. The gain data for the measured and simulated antennas is shown in Table III. A comparison between measured boresight gain for the solar and copper Vivaldis are shown in Fig. 3.

The $S_{11}$ response, the efficiency and the gain values are lower for the solar antenna when compared to the copper antenna suggesting increased losses. Simulated results show that some of this loss is due to current flow along the edges of

TABLE II

ANTENNA $S_{11}$ PERFORMANCE

\begin{tabular}{cccccc}
\hline \multirow{2}{*}{ Antenna } & Min $\mathrm{S}_{11}$ & Bandwidth & \multicolumn{3}{c}{ Efficiency } \\
\cline { 4 - 6 } & $(\mathrm{GHz})$ & $(\%)$ & $0.95 \mathrm{GHz}$ & $1.87 \mathrm{GHz}$ & $2.45 \mathrm{GHz}$ \\
\hline Meas a-Si & 0.938 & 127 & N/A & N/A & N/A \\
Sim a-Si & 0.921 & 123 & $84 \%$ & $78 \%$ & $70 \%$ \\
Meas Cu & 0.576 & 159 & N/A & N/A & N/A \\
Sim Cu & 0.752 & 148 & $95 \%$ & $89 \%$ & $77 \%$ \\
\hline \hline
\end{tabular}

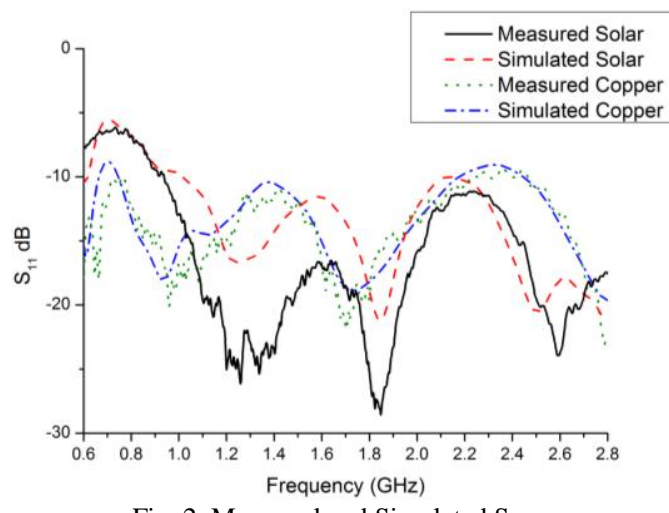

Fig. 2. Measured and Simulated $S_{11}$
TABLE III

ANTENNA Gain PERformance

\begin{tabular}{ccccc}
\hline \hline $\begin{array}{c}\text { Frequency } \\
(\mathrm{GHz})\end{array}$ & $\begin{array}{c}\text { Measured } \\
\text { Solar }(\mathrm{dBi})\end{array}$ & $\begin{array}{c}\text { Simulated } \\
\text { Solar }(\mathrm{dBi})\end{array}$ & $\begin{array}{c}\text { Measured } \\
\text { Copper }(\mathrm{dBi})\end{array}$ & $\begin{array}{c}\text { Simulated } \\
\text { Copper }(\mathrm{dBi})\end{array}$ \\
\hline 0.95 & 0.04 & 0.31 & 1.05 & 0.92 \\
1.87 & 3.91 & 4.2 & 3.84 & 4.66 \\
2.45 & 5.28 & 4.52 & 5.46 & 5.19 \\
\hline \hline
\end{tabular}

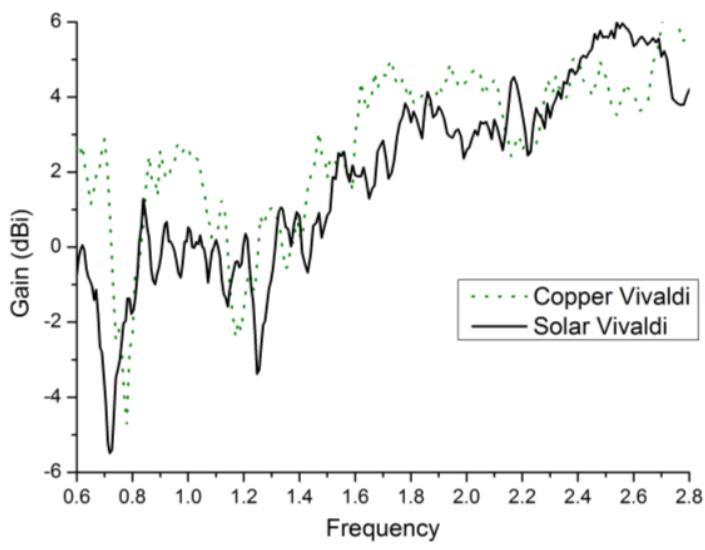

Fig. 3. Measured Boresight Gain

intersections between the solar cells as shown in Fig. 4.

The $\mathrm{X}-\mathrm{Z}$ beamwidth is narrower than the $\mathrm{X}-\mathrm{Y}$ beamwidth for all frequencies. In addition the beamwidths narrow as frequency increases with the lower frequency being omnidirectional in the $\mathrm{X}-\mathrm{Y}$ plane. Radiations plots for the antenna at $950 \mathrm{MHz}, 1.87 \mathrm{GHz}$ and $2.45 \mathrm{GHz}$ are shown in Fig. 5, Fig. 6 and Fig. 7 respectively.

\section{Solar Cell Power Generation}

Solar measurements were carried out using a 1450 Lux light source positioned $960 \mathrm{~mm}$ from the solar panel. The solar Vivaldi antenna has been compared to an intact solar panel. The intact solar panel was also supported on an FR 4 substrate to prevent any differences in thermal properties. The outline of the Vivaldi slot is shown imposed on the intact solar panel in Fig. 8 with the removed sections of silicon marked in green.

As the Vivaldi slot was centred between adjacent solar cells it removes equal amounts of silicon from each cell and splits the panel into two strings of series connected cells. Section A removed $14.40 \%$ of the silicon from the affected cell. Section

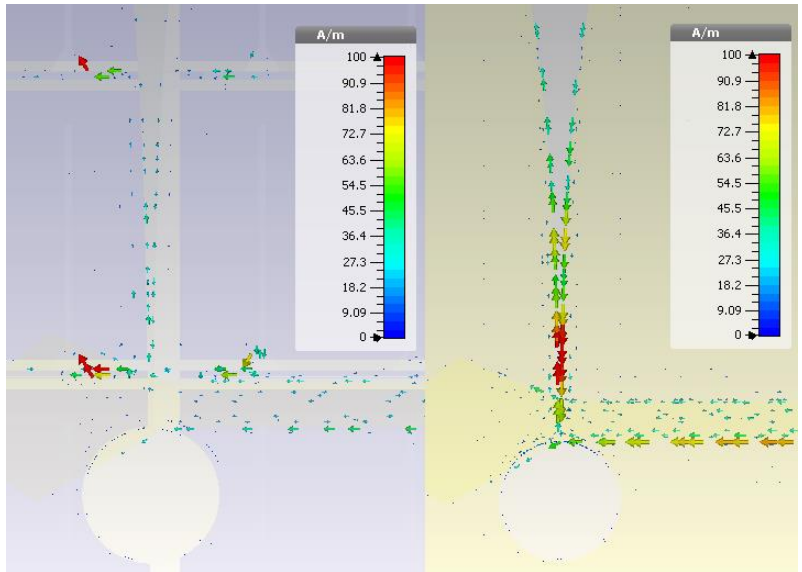

Fig. 4. Antenna Surface Currents for Solar (Left) and Copper (Right) 


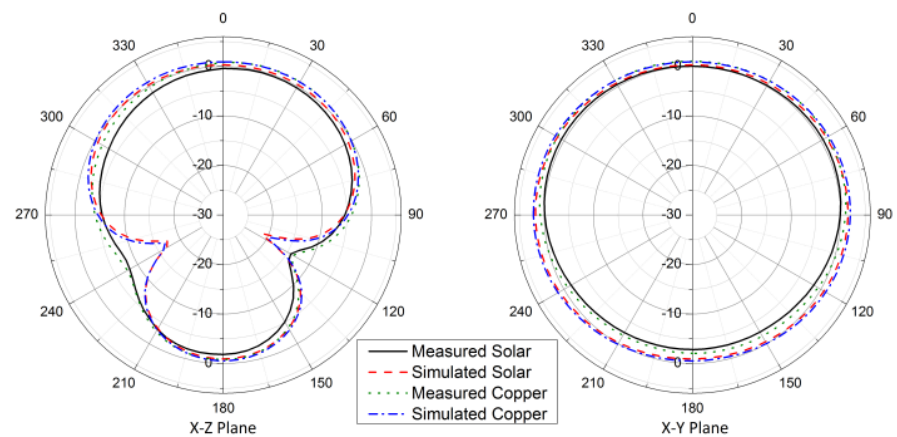

Fig. 5. Radiation pattern at $950 \mathrm{MHz}$

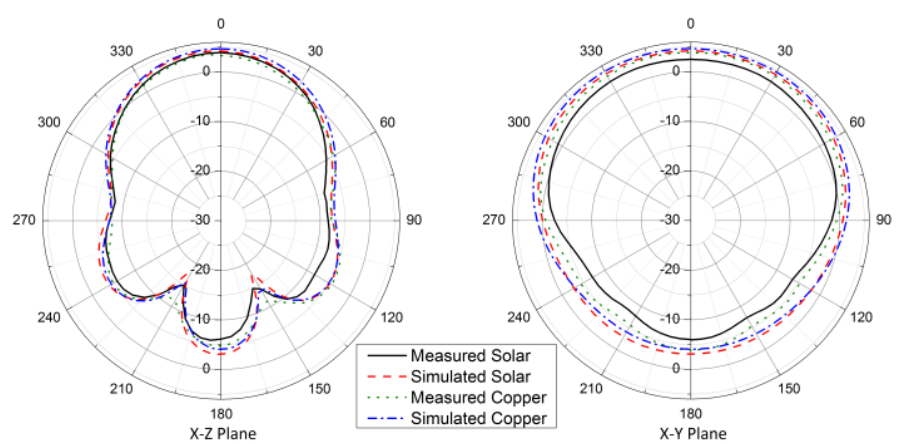

Fig. 6. Radiation pattern at $1.87 \mathrm{GHz}$

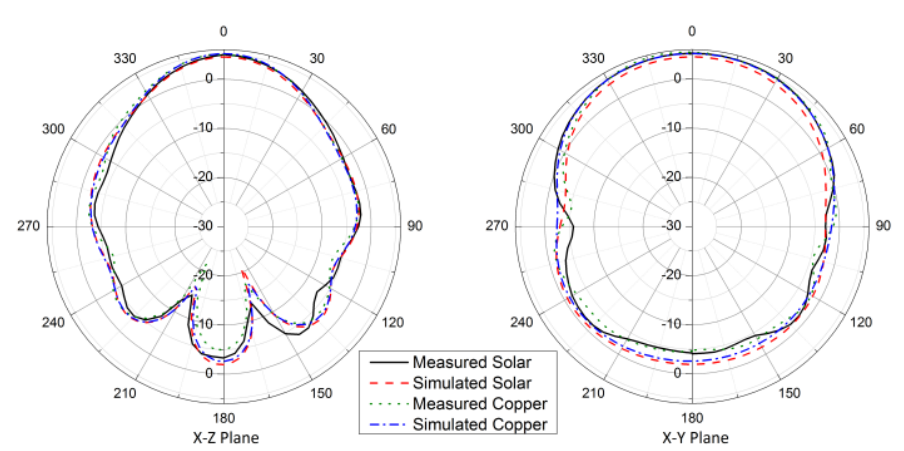

Fig. 7. Radiation pattern at $2.45 \mathrm{GHz}$

$\mathrm{B}$ removed $1.71 \%$ and section $\mathrm{C}$ was $1.89 \%$. This resulted in a loss of $3.6 \%$ of the total available silicon. As section A was the largest cut in a single cell, thereby setting the current limit of that string.

The maximum power point of the full solar cell was $51.7 \mathrm{~mW}(4.25 \mathrm{~V} \times 12.2 \mathrm{~mA})$. With the strings reconnected, the maximum power point of the solar Vivaldi antenna was $27.4 \mathrm{~mW}(2.67 \mathrm{~V} \times 10.3 \mathrm{~mA})$. This was a $15.57 \%$ decrease in current at the maximum power point which was proportionate with the percentage of material removed. Measured solar power outputs are shown in Fig. 9.

If this antenna was to go into production, the solar cell could be redesigned to ensure each cell in the series had an equal volume of a-Si. In [12], a custom a-Si:H solar cell was manufactured to conform to the shape required for a slot antenna. Laser etching of the layers of the solar cell in a certain pattern make it possible to achieve the desired shape without requiring modification to existing production equipment [13]. This would optimize the cells to suit the available space of the solar Vivaldi antenna and improve the output power of the final solar panel.

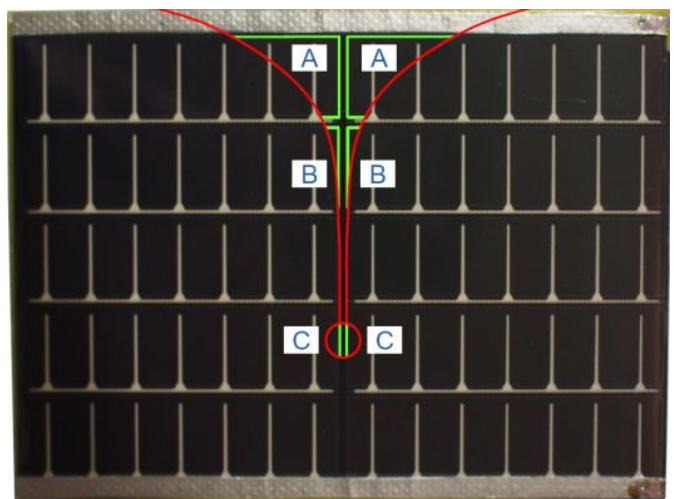

Fig. 8. Sections removed from solar cell

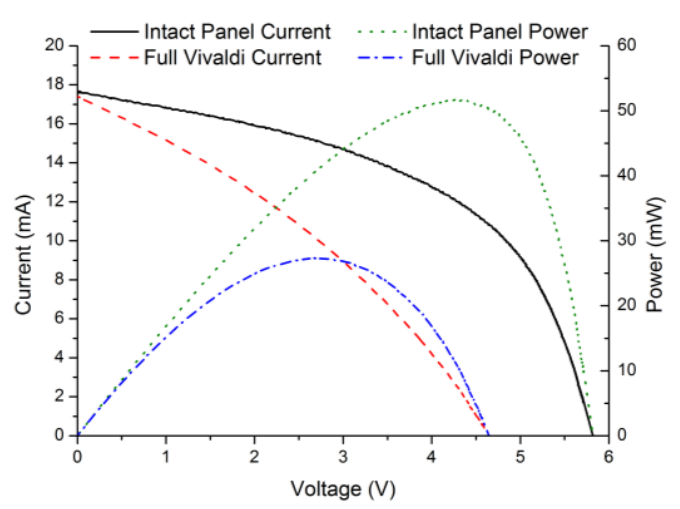

Fig. 9. Solar performance results

\section{ENERGY SCAVENGING POTENTIAL}

An 8-stage Villard cascade voltage multiplier circuit was designed to test the energy scavenging potential of the solar Vivaldi. The Villard cascade configuration is shown in Fig. 10 where the $\mathrm{C} 1=100 \mathrm{pF}, \mathrm{R} 1=10 \mathrm{M} \Omega$ and D1 is a HSMS-268CTR1G. A $100 \mathrm{pF}$ storage capacitor and $10 \mathrm{M} \Omega$ load were chosen to ensure quick charge and discharge during testing.

A Hewlett Packard 8648C signal generator with a MiniCircuits ZFL-2500 $31 \mathrm{~dB}$ amplifier and a horn antenna located $1 \mathrm{~m}$ from the solar Vivaldi was used for testing. The system was measured between the signal generator and the horn, giving a gain of $31 \mathrm{~dB}$ at $950 \mathrm{MHz}, 32 \mathrm{~dB}$ at $1.87 \mathrm{GHz}$ and $31 \mathrm{~dB}$ at $2.45 \mathrm{GHz}$. The horn antenna gain was $9.6 \mathrm{dBi}$ at $950 \mathrm{MHz}, 10.8 \mathrm{dBi}$ at $1.87 \mathrm{GHz}$ and $12.4 \mathrm{dBi}$ at $2.45 \mathrm{GHz}$.

The voltage multiplier output was measured in an anechoic chamber to minimise reflection and the inverse-square law was used to calculate the power density $\left(P_{D}\right)$ at the receive antenna, results are shown in Table IV.

It is clear that with an incident power density of $1.6 \mu \mathrm{W} / \mathrm{cm}^{2}$ at $950 \mathrm{MHz}, 2.7 \mu \mathrm{W} / \mathrm{cm}^{2}$ at $1.87 \mathrm{GHz}$ or $17.4 \mu \mathrm{W} / \mathrm{cm}^{2}$ at $2.45 \mathrm{GHz}$ the rectenna can exceed the $1.8 \mathrm{~V}$

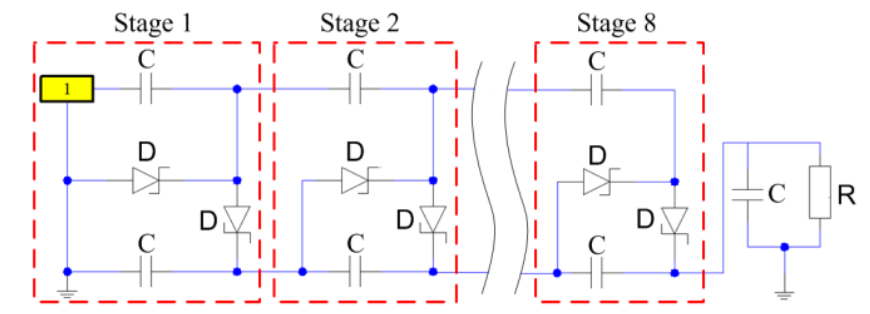

Fig. 10. Villard Cascade Voltage Multiplier Circuit 
TABLE IV

MEASUREd DC OUTPUT FOR DiFFERENT Signal GENERATOR POWERS

\begin{tabular}{|c|c|c|c|c|c|c|c|c|c|c|}
\hline \multirow[b]{2}{*}{ Freq } & \multicolumn{2}{|c|}{$-20 \mathrm{dBm}$} & \multicolumn{2}{|c|}{$-17.5 \mathrm{dBm}$} & \multicolumn{2}{|c|}{$-15 \mathrm{dBm}$} & \multicolumn{2}{|c|}{$-12.5 \mathrm{dBm}$} & \multicolumn{2}{|c|}{$-10 \mathrm{dBm}$} \\
\hline & $\begin{array}{c}P_{D} \\
\left(\mu \mathrm{W} / \mathrm{cm}^{2}\right)\end{array}$ & $\begin{array}{l}\text { Voltage } \\
\text { (V) }\end{array}$ & $\begin{array}{c}P_{D} \\
\left(\mu \mathrm{W} / \mathrm{cm}^{2}\right)\end{array}$ & $\begin{array}{c}\text { Voltage } \\
(\mathrm{V})\end{array}$ & $\begin{array}{c}P_{D} \\
\left(\mu \mathrm{W} / \mathrm{cm}^{2}\right)\end{array}$ & $\begin{array}{c}\text { Voltage } \\
(\mathrm{V})\end{array}$ & $\begin{array}{c}P_{D} \\
\left(\mu \mathrm{W} / \mathrm{cm}^{2}\right)\end{array}$ & $\begin{array}{c}\text { Voltage } \\
\text { (V) }\end{array}$ & $\begin{array}{c}P_{D} \\
\left(\mu \mathrm{W} / \mathrm{cm}^{2}\right)\end{array}$ & $\begin{array}{c}\text { Voltage } \\
(\mathrm{V})\end{array}$ \\
\hline 0.95 & 0.9 & $\begin{array}{c}1.25 \mathrm{~V} \\
(0.16 \mu \mathrm{W})\end{array}$ & 1.6 & $\begin{array}{c}2.09 \mathrm{~V} \\
(0.44 \mu \mathrm{W})\end{array}$ & 2.9 & $\begin{array}{c}3.25 \mathrm{~V} \\
(1.06 \mu \mathrm{W})\end{array}$ & 5.1 & $\begin{array}{c}4.56 \mathrm{~V} \\
(2.08 \mu \mathrm{W})\end{array}$ & 9.1 & $\begin{array}{c}5.53 \mathrm{~V} \\
(3.06 \mu \mathrm{W})\end{array}$ \\
\hline 1.87 & 1.5 & $\begin{array}{c}1.22 \mathrm{~V} \\
(0.15 \mu \mathrm{W})\end{array}$ & 2.7 & $\begin{array}{c}2.01 \mathrm{~V} \\
(0.40 \mu \mathrm{W})\end{array}$ & 4.8 & $\begin{array}{c}2.92 \mathrm{~V} \\
(0.85 \mu \mathrm{W})\end{array}$ & 8.5 & $\begin{array}{c}3.97 \mathrm{~V} \\
(1.57 \mu \mathrm{W})\end{array}$ & 15.2 & $\begin{array}{c}4.78 \mathrm{~V} \\
(2.28 \mu \mathrm{W})\end{array}$ \\
\hline 2.45 & 1.7 & $\begin{array}{c}0.51 \mathrm{~V} \\
(0.03 \mu \mathrm{W})\end{array}$ & 3.1 & $\begin{array}{c}0.83 \mathrm{~V} \\
(0.06 \mu \mathrm{W})\end{array}$ & 5.5 & $\begin{array}{c}1.27 \mathrm{~V} \\
(0.16 \mu \mathrm{W})\end{array}$ & 9.8 & $\begin{array}{c}1.73 \mathrm{~V} \\
(0.30 \mu \mathrm{W})\end{array}$ & 17.4 & $\begin{array}{c}2.06 \mathrm{~V} \\
(0.42 \mu \mathrm{W})\end{array}$ \\
\hline
\end{tabular}

and $132 \mathrm{nW}$ required for a microcontroller [7] to maintain deep sleep mode.

\section{CONCLUSIONS}

An ultra-wideband $(0.938-2.45 \mathrm{GHz})$ Vivaldi antenna made from an amorphous silicon solar cell was reported for the first time. The wide bandwidth included GSM and WLAN channels to support devices used in remote locations. At all measured frequencies, the beamwidth exceeded $110^{\circ}$ in at least one plane to order to improve the probability of suitable orientations for RF transmission, solar generation and wireless energy scavenging.

Simulated and measured results for the solar Vivaldi showed that the narrow spacing between the rear contacts of each solar cell is sufficiently smaller than a wavelength to ensure minimal impact. Simulated results suggest the solar antenna is around $10 \%$ less efficient compared to an equivalent copper. Measured gain is $1 \mathrm{~dB}$ less at $950 \mathrm{MHz}$ when compared to the equivalent copper antenna, which suggests there were increased losses due to the silicon, encapsulating material and current flow along intersections between solar cells. The measured gain values are $\sim 1 \mathrm{~dB}$ higher than other ultra wideband solar antennas.

Solar measurements have shown that the removal of silicon to create the solar Vivaldi reduced the power output of the solar cell. Measured maximum power point for the solar Vivaldi is $47 \%$ lower than that of an intact panel. This can be improved by manufacturing the solar panel with the Vivaldi slot built in and equal silicon area in each cell.

Calculations of energy scavenging performance showed that while power received is low there is potential to maintain a microcontroller in deep sleep mode while energy is stored for use later.

\section{ACKNOWLEDGMENT}

The Authors would like to thank Eamonn Murphy (DIT) for technical support during solar measurements.

\section{REFERENCES}

[1] J.A. Paradiso, T. Starner, "Energy Scavenging for Mobile and Wireless Electronics" Pervasive Computing, IEEE, vol.4, no.1, pp.18,27, Jan.March 2005.

[2] M. Danesh, J.R. Long, "An autonomous wireless sensor node using a solar cell antenna for solar energy harvesting", Microwave Symposium Digest (MTT), 2011 IEEE MTT-S International, 5-10 June 2011.

[3] M. Danesh, J.R. Long, "Solar cell antenna for autonomous wireless smart sensors", Smart Systems Integration (SSI), Dresden, Germany, March 22-23 2011.
[4] S.V. Shynu, M.J. Roo Ons, M.J. Ammann, S.J. McCormack, B. Norton, "Dual Band a-Si:H Solar-Slot Antenna for 2.4/5.2GHz WLAN Applications" 3rd Eur. Conf. on Antennas $\backslash \&$ Propag., 408-410, 2009.

[5] J. Tavares, N. Barroca, H.M. Saraiva, L.M. Borges, F.J. Fernando, C. Loss, R. Salvado, P. Pinho, R. Goncalves, N. Borges Carvalho, "Spectrum opportunities for electromagnetic energy harvesting from 350 mhz to $3 \mathrm{GHz}$ ", Medical Information and Communication Technology (ISMICT), $20137^{\text {th }}$ International Symposium on, pp. 126,130, 6-8 March 2013.

[6] H.J. Visser, AC.F. Reniers, J.AC. Theeuwes, "Ambient RF Energy Scavenging: GSM and WLAN Power Density Measurements", 38th European Microwave Conference, pp.721,724, 27-31 Oct. 2008

[7] Microchip Device Document, 64/80/100-Pin, General Purpose, 16-Bit Flash Microcontrollers with LCD Controller and nanoWatt XLP Technology, Microchip Technology Inc. 2010.

[8] F. Congedo, G. Monti, L. Tarricone, V. Bella, "A 2.45-GHz Vivaldi Rectenna for the Remote Activation of an End Device Radio Node" Sensors Journal, IEEE, vol.13, no.9, pp.3454,3461, Sept. 2013

[9] PowerFilm Solar OEM Flysheet, OEM Components, PowerFilm Solar Inc. 2008.

[10] J.S. Kang, "Structural Integration of Silicon Solar Cells and Lithium-ion Batteries Using Printed Electronics" Ph.D. dissertation, Dept. Mech. Eng., UCLA 2012.

[11] D. Gaetano, A. Dumoulin, M.J. Ammann, P. McEvoy, "Conformal UWB impulse antenna for pipe telemetry," Antennas and Propagation Conference (LAPC), Loughborough, 14-15 Nov. 2011

[12] S. Vaccaro, J.R. Mosig, P. de Maagt, "Two Advanced Solar Antenna "SOLANT" Designs for Satellite and Terrestrial Communicaions", IEEE Transactions on Antennas and Propagation, vol. 51, no. 8, pp. 2028-2034, August 2003.

[13] S. Nakano, T. Matsuoka, S. Kiyama, H. Kawata, N. Nakamura, Y. Nakashima, S. Tsuda, H. Nishiwaki, M. Ohnishi, I. Nagaoka, Y. Kuwano, "Laser Patterning Method for Integrated Type a-Si Solar Cell Submodules" Japanese Journal of Applied Physics, vol. 25, no. 12, pp. 1936-1943, December, 1986. 